\title{
ИССЛЕДОВАНИЕ УРОВНЯ АЛЕКСИТИМИИ И СОВЛАДАЮЩЕГО ПОВЕДЕНИЯ ПАЦИЕНТОВ С АУТОИММУННЫМ ТИРЕОИДИТОМ И РЕВМАТОИДНЫМ АРТРИТОМ
}

\author{
Буйдина Т.А., Русина Н.А., Зубова А.В. \\ ФГБОУ ВО «Ярославский государственный медицинский университет» \\ чуз Клиническая больница «РЖД-Медицина», Ярославль
}

ЦЕЛь: исследование направлено на выявление преобладающих эмоциональных проявлений и совладающего поведения пациентов с аутоиммунными заболеваниями.

МАТЕРИАЛЫ И МЕТОДЫ: обследовано 67 человек обоего пола, от 33 до 65 лет, давностью заболевания от 10+-2,5года, 32 пациента с ревматоидным артритом (РА) с минимальной активностью на фоне постоянной терапии цитостатиками и 35 пациентов с аутоиммунным тиреоидитом (АИТ) в фазе медикаментозной компенсации тиреоидными препаратами. Применялись: методика диагностики копинг-механизмов Э. Хейма, Торонтская Алекситимическая Шкала, «Шкала дифференциальных эмоций» К. Изарда в адаптации А.Б. Леоновой. Коэффициент ранговой корреляции Ч. Спирмена и сравнительный анализ по U критерию Манна-Уитни-Вилкоксона.

PЕЗУЛЬТАТЫ: у пациентов с РА выявлена взаимосвязь между шкалами негативных и тревожно-депрессивных эмоций. Существует тенденция взаимодействия между этими шкалами и индексом алекситимии: чем сильнее пациент с РА склонен к негативным и тревожно-депрессивным эмоциям, тем сложнее ему дается проявление эмоций. Выявлена обратная корреляция между шкалой позитивных эмоций и возрастом пациентов, которая позволяет предположить, что чем старше пациент с РА, тем слабее его стремление проявлять позитивные эмоции. Возможно, с возрастом болевые ощущения и ограничения подвижности усиливаются, что снижает уровень позитивных эмоций. Взаимосвязи между индексом алекситимии и типом копинг-стратегии не выявлено, но определена тенденция: пациент с РА тем реже использует адаптивные когнитивные и эмоциональные копинг-стратегии, чем выше его уровень алекситимии. Пациенты с РА имеют ограниченность проявлений эмоциональных реакций с подавлением агрессии и враждебности, бедность мимики и жестикуляции и используют копинг-механизмы «отрицание проблем» и «стоицизм» в качестве «фасада благополучия», являющегося характерным стилем адаптации при РА.

У пациентов с АИТ присутствует взаимосвязь между шкалами негативных и тревожно-депрессивных эмоций, но она сильнее, чем среди пациентов с РА. Возраст пациентов коррелирует со шкалой алекситимии: чем старше пациент с АИТ, тем сложнее ему выражать свои эмоции, поскольку пациент становится с возрастом более сдержанным. Обнаружена тенденция взаимосвязи между возрастом и шкалой позитивных эмоций. Это позволяет предполагать, что чем старше пациент с АИТ, тем более свойственен ему позитивный настрой. Возможно потому, что пациент не испытывает сильных болевых ощущений, он адаптируется к своему образу жизни, а заместительная терапия тиреоидными препаратами позволяет сохранять стабильность общего состояния. Взаимосвязи между индексом алекситимии и типом копинг-стратегий среди пациентов с АИТ не выявлено. Но оказалось, что чем сильнее пациент проявляет позитивные эмоции, тем чаще он стремится выбирать адаптивную стратегию поведения в ситуации стресса.

ВывОДЫ: в группе с РА выявлена взаимосвязь между уровнем алекситимии пациентов и конструктивностью их копинга. С возрастом у пациентов с РА снижается стремление проявлять позитивные эмоции. Пациенты с АИТ с возрастом сильнее стремятся именно к позитивному настрою, но в целом становятся более алекситимичными. Чем активнее пациент с АИТ проявляет позитивные эмоции, тем чаще он стремится выбирать адаптивную поведенческую стратегию в ситуации стресса.

КЛЮЧЕВЫЕ СЛОВА: эмоции, совладающее поведение, аутоиммунные заболевания 